\title{
The Big Reveal: COVID-19 and Globalization's Great Transformations
}

\author{
Kathleen R. McNamara $\odot$ and Abraham L. Newman $₫$
}

\begin{abstract}
Analysis of the post-COVID world tends to gravitate to one of two poles. For some, the pandemic is a crisis that will reshuffle the decks, producing a fundamental reordering of global politics. For others, the basic principles of the international order are likely to remain much the same, driven largely by the emerging bipolar system between the US and China. We find both narratives dissatisfying, as the former overinterprets the causal role of the pandemic itself, while the latter underappreciates the critical ways in which global politics have been transformed beyond the state-centered system of the Cold War. We argue instead that the pandemic exposes underlying trends already at work and forces scholars to open the aperture on how we study globalization. Most centrally, we contend that globalization needs to be seen not just as a distributional game of winners and losers but rather a more profoundly transformational game that reshapes identities, redefines channels of power and authority, and generates new sites for contentious politics. We draw on emerging work to sketch out a theoretical frame for thinking about the politics of globalization, and assess some of the key policy arenas where COVID-19 is accelerating the transformative effects of globalization. In so doing, we suggest a roadmap to a post-pandemic research agenda for studying global markets that more fully captures these transformations and their implications for world politics.
\end{abstract}

On 15 March 2020, the national German newspaper Die Welt reported that the Trump administration had offered a "large sum" of money to a German biotech company developing a COVID-19 vaccine. ${ }^{1}$ The administration refutes the account but the German government took the threat seriously, buying a 300 million euro stake in the company and deriding US efforts to acquire "exclusive access" to vaccine research. ${ }^{2}$ Similar breaking news stories have noted worrying tensions over the

Editor's note: This article is part of an online supplemental issue on COVID-19 and international relations. The authors were invited by IO's editorial team and guest editor Michael C. Horowitz. The manuscript was reviewed based on written non-anonymous reviewer comments and during an online workshop. The revised manuscript was evaluated by the IO editorial team. We appreciate the support of Perry World House at the University of Pennsylvania for making this possible.

1. See Jan Dams, "Diese Erfahrung wird Europa so schnell nicht vergessen." Die Welt, 15 March 2020; Katrin Bennhold and David Sanger, "US Offered 'Large Sum' To German Company for Access to Coronavirus Vaccine Research, German Officials say" New York Times, 15 March 2020.

2. "Germany to buy stake in CureVac as world races for COVID-19 vaccine," Reuters, 15 June 2020. 
mass production of an eventual vaccine and over supply chains for personal protective equipment (PPE) ${ }^{3}$

Such anecdotes from the initial COVID-19 response suggest how the shock of the coronavirus pandemic has made starkly visible the often underappreciated ways in which globalization has transformed global politics. For the last three decades, international flows of information, money, and goods and services proliferated, breaking apart national economies and reengineering them into world spanning networks. Rather than simply creating a Ricardian paradise of win-wins and growing prosperity for all, however, this deeply intertwined interdependence has generated new vulnerabilities and sources of power and authority—globally, between nation-states, firms, non-state actors, and within domestic political systems. In this paper we lay out key elements of this shifting political landscape and propose a post-pandemic research agenda to better understand our world.

We challenge both those observers who see the pandemic as a definitive break with the past as well as those who see it simply as an extension of ongoing great power competition. Instead, we argue that the pandemic exacerbates underlying trends already at work and forces scholars to open the aperture on how we study globalization. Most centrally, we contend that globalization needs to be seen not just as a distributional game of winners and losers but rather as a more profoundly transformational game. In other words, economic interdependence is altering both the issues and identities that are important as well as actors' opportunities to fight their political battles. We see these transformational dynamics at work in at least four areas: inequality within and across societies, new forms of economic statecraft, existential ecological threats, and the trajectory of the digital revolution.

COVID-19 by itself is not the primary source of the tensions in areas from inequality to climate change, but the virus has effectively exacerbated the trade-offs and made salient the challenges of governing in a tightly connected world. The global pandemic therefore provides a useful lens to reveal how we should be studying, understanding, and engaging with the politics of globalization going forward. This agenda will require scholars to more deeply integrate issues of power and identity into their analysis of global markets, while also recognizing the ways in which globalization has transformed political authority.

We begin by noting the limits of much of the standard scholarship in international political economy, which emphasizes the distributional impacts of globalization and the sources of policies of openness. We draw on emerging work to sketch out an alternative theoretical frame for thinking about the politics of globalization today, one that probes into the ways economic interdependence is reshaping identities, relocating political authority, and creating new sites for contentious politics. We then turn to assess some of the key policy arenas where the transformative effects of globalization are being felt, highlighting in particular how COVID-19 has made them even more

3. Bill Bostock, "Sanofi walked back a promise to give the US priority access to its coronavirus vaccine after outrage from the French government," Business Insider, 15 May 2020. 
visible. In so doing, we suggest a roadmap to a post-pandemic research agenda for global markets that more fully captures these transformations and their implications for world politics. ${ }^{4}$

\section{Everything Changed But We Weren't Looking}

The debate on the post-COVID world tends to gravitate to one of two poles. For some, the pandemic is a crisis that will reshuffle the decks, producing a fundamental reordering of global politics. ${ }^{5}$ For others, the basic principles of the international order are likely to remain much the same, underscoring the importance of the emerging bipolar system between the US and China. ${ }^{6}$ We find both narratives dissatisfying, as the former overinterprets the causal role of the pandemic itself, while the latter underappreciates the critical ways in which global politics has been transformed from the highly state-centered system of the Cold War.

Unfortunately, standard international political economy accounts have left us with relatively few tools to grapple with such dynamics. ${ }^{7}$ The dominant approach used to understand the early years of deepening globalization drew largely on neoclassical, mainstream economics for a depiction of how markets work. ${ }^{8}$ Importantly, economic openness reshuffled the distributional consequences for economic sectors, firms, or class groups, but it hardly transformed their political identities and perceived interests.

Early theoretical moves favoring this neoliberal-informed rationalist approach, in combination with the assumption that domestic and international politics were distinct and separate, focused the field on a narrow set of questions concerning the political conditions that favor or oppose openness. Empirically, this work tended to privilege conventional trade in physical goods. Most studies attempted to understand why countries would liberalize their markets to international trade and finance and, relatedly, how international institutions like the World Trade Organization or Bilateral Investment Treaties could facilitate such efforts. ${ }^{9}$ Substantively, this approach generated a number of important blind spots as to the consequences of openness, particularly as globalization moved beyond container ships and accelerated through global data, finance, supply chains, and migration (including viral migration of pandemics).

4. For an elaboration of a programmatic approach to such a roadmap, see the work of the Global Political Economy Project, retrieved from < https://mortara.georgetown.edu/research/global-political-economyproject-gpep/who-we-are/>.

5. Steven Erlanger, "Spread of Virus Could Hasten the Great Coming Apart of Globalization," New York Times, 25 Feb 2020.

6. See Daniel Drezner, "The Most Counterintuitive Prediction about World Politics and the Coronavirus," Washington Post, 30 March 2020; Drezner 2020.

7. See Lipscy's contribution to this symposium for an extensive discussions of these issues.

8. For a summary, see Lake 2009.

9. See Büthe and Milner 2008; Lake 2009; Mansfield, Milner, and Pevehouse 2007. 
In the face of the global financial crisis and the rise of populist parties, many scholars have shifted their attention to the sources of backlash and drivers of potential closure. ${ }^{10}$ Once again, the underlying assumption behind much of this work is that globalization generates distribution consequences among the material winners and losers of economic openness and that international institutions may be well positioned to solve resulting cooperation problems. Empirically, then, this research agenda focused on a specific set of questions such as measures of relative openness (tariff rates, levels of FDI, or gravity models of trade) as well as indicators of cooperation (dispute settlement mechanisms, participation in international organizations, or signing BITs). ${ }^{11}$

Theoretically, scholars have therefore evaded one of the most interesting and consequential implications of the nature of globalization today: the role of power and culture and the institutionalization of transnational political authority in both formal and everyday ways. In a review of international political economy work, Robert Keohane concludes, "I would urge scholars now active in the IPE field to spend more of their time pondering big questions about change, and asking not what the best existing research tells us about them, but what interpretive leaps may be necessary to point the way to more profound and relevant scholarship." 12 Fortunately, there is plenty of promising work across political science and other disciplines that can help us take that leap.

\section{Reimagining Identity \& Authority in Global Markets}

Our overall contention is that globalization-the interpenetration of markets across national borders-is transforming politics in the twenty-first century in ways drawn in sharp relief by the coronavirus pandemic. The pandemic is fundamentally a product of globalization, as it was carried from country to country on the backs of global transport, migration, and business. But more fundamentally, the impact and response of the pandemic is being filtered by long-term changes sparked by globalization in terms of what is viewed as contentious and where political contention can play out.

Below, we briefly map an account of globalization that focuses on its transformation of identity and authority, before demonstrating the potential of such an account to enable us to understand the post-pandemic political economy. Our account rests on two key assumptions. First, we highlight how global markets are constituted by people with particular sets of intersecting identities that are shaped by social relations and always refracted through power. Deepening globalization has altered and transformed those identities in profoundly consequential ways as it implicates both what individuals see as important and what they are willing to

10. See Owen and Johnston 2017; Owen and Walter 2017.

11. See Allee and Peinhardt 2011; Allee and Scalera 2012.

12. Keohane 2009. 
fight over, even for those with little felt connection to the global economy. Second, whereas in the past, many assumed that such contentious politics were firmly anchored around the political authority of the nation-state-as the international realm meant state-to-state negotiations or technocratic delegation to international organizations-political authority is now exerted and contested from the town level through state levels, regional levels, national levels, transnational, and supranational levels. Globalization has simultaneously broken the monopoly of authority held by the nation-state and created new opportunity structures for change and sites for contestation. ${ }^{13}$

\section{Global Markets and Identity}

Our theoretical framework starts with the foundational assumption that markets themselves are constructed through the social interactions of human beings. ${ }^{14}$ These identities always structure and are structured by power relations. ${ }^{15}$ In this constructivist approach, we can't model, understand, or predict how the politics of global markets will unfold unless we first grasp the identities of the actors involved and how those identities generate specific sets of market cultures, meanings, and interests. ${ }^{16}$ As Kathleen McNamara has argued, this approach has transformational potential built in: different times and places will have different cultures, which are fundamental to the way we see the world and to the meanings we ascribe to anything from the value of the dollar to the desirability of free trade. ${ }^{17}$

Using this lens allows us to open up our research to how globalization creates fundamental changes in the outlooks, ideas, and practices of actors as global markets morph and change. For decades, national market systems produced political debates anchored on left-right ideological conflicts over levels of redistribution. As markets have integrated, they have both transformed these ideological debates and raised new fundamental conflicts over the site of control between states and other political authorities. ${ }^{18}$ Standard class conflicts have given way to new cleavages that interact economic conditions with local community identities and positions within global society. ${ }^{19}$ The pandemic is the latest of globalization's shocks to raise fundamental questions about people's commitments to global public goods, the moral responsibility to others, as well as about the value of liberal market integration. ${ }^{20}$ Instead of seeing the pandemic as what economists might call a "negative externality" of market integration, we need to see it as knit into the reality of markets operating

13. Farrell and Newman 2016; 2019 a.

14. Fligstein 2002.

15. Barnett and Duvall 2005.

16. See Abdelal, Blyth, and Parsons 2011; Best and Paterson 2010.

17. See McNamara 1999; McNamara 2002.

18. See Garrett 1998; Mosley 2003.

19. McNamara 2017.

20. Barnett 2020. 
within, and driven by, social life. The foundation for such a view of markets already exists, even if it has not gotten much traction in the mainstream international relations study of IPE..$^{21}$

A specific example of how a focus on identity would allow us to better understand the outbreak of and response to the pandemic can be found in the recent literature on "racial capitalism." Nancy Leong describes racial capitalism as "the process of deriving social and economic value from the racial identity of another person [that] is a longstanding, common, and deeply problematic practice." 22 There are a host of questions around how the changing construction of race over time both causes and is shaped by dynamics in the global political economy, but the rational-materialist approach dominating the high status IPE field has left them largely unasked. ${ }^{23}$ The Trump administration's insistence on labeling COVID-19 the Wuhan Flu may seem like a simpleton's tactic to avoid blame, but in demonizing China, the tactic further demonstrates the power of race and racism in international politics, and the role such identity construction plays as a political resource. ${ }^{24}$

If we can rebuild our model of markets around social identity, we can begin to grapple with how race matters for the way that markets have been built historically and function today, and how economic wealth and political power accrues to some states over others in the international system. ${ }^{25}$ While scholars outside mainstream IPE have studied colonialization and empire in ways that do bring race in, we need to put race-and all other salient identities - at the core of our study of IPE to more fully account for the outcomes of power and wealth within a globalized world. Such an approach could also contribute to understanding the mass mobilization supporting anti-racism protests in the United States around the Black Lives Matter movement, as well as its spontaneous reverberations cross-nationally.

The fact that racism has been tightly linked to outcomes of the pandemic, as we discuss below, only makes this approach more vital. ${ }^{26}$ We need research that takes identity - starting with race but including gender, sexual orientation, ethnicity, class identities, and beyond, and the broader cultures those identities are situated in - as a variable in terms of both causes and outcomes of global markets. Doing so will allow us to better capture the reality of globalization's transformation potential and the types of political conflicts, cleavages, and coalitions that it is generating.

21. See McNamara 2009; Smelser and Swedberg 2005. Our research only finds a total of 15 articles with a constructivist perspective published out of a total of 310 articles in International Organization since 2010 , indicating the limited use of this approach.

22. Leong 2013.

23. See Guisinger 2017; Tilley and Shilliam 2018.

24. Buzas 2020.

25. Persaud and Sajed 2018.

26. For real time data on the differential impacts of COVID-19 on communities of color, see $<$ https:// covidtracking.com/race $>$. 


\section{Political Authority Below, Above, and Across the Nation}

Globalization is not only shaping what is being contested but where. ${ }^{27}$ As the pandemic has demonstrated, the scale and level of political authority is becoming ever more fluid, while at the same time dramatically more contested. Pandemic politics are deeply contentious, both within national communities, above and across nation-states in new, emergent sites of authority and governance, and in the fragmentation of previously robust political communities. We now need to reorient IPE to take account of this politicization and contested authority to find durable solutions to the current global pandemic and longer term challenges raised by globalization.

In some cases, these relationships can be understood by using the lens of hierarchy studies. ${ }^{28}$ In this approach, global politics is understood as a hierarchically structured polity rather than through the canonical view that international relations takes place in a world of anarchy or lack of legitimate authority above the state. Hierarchies are "any system through which actors are organized into vertical relations of super- and subordination." 29 They are thus inherently political and intrinsically about power, making up systems that stratify, rank, and organize the relations not only among states but also other kinds of actors, and often even among a mix of different actors within a single structure of differentiation.

In other cases, however, these relationships are less clear. Globalization has generated new sites of authority above the nation-state and also created new channels of collaboration among actors that sit below it. ${ }^{30}$ This allows disaffected actors, who were previously stuck in a world of comparative politics, to relitigate their objectives transnationally. Take the case of Brexit. The UK Independence Party was repeatedly denied electoral success under the UK "first past the post" electoral system. It then strategically used the proportional representation system of the European Parliament to gain traction and then raise salience for the Brexit platform. ${ }^{31}$ The overlapping rules of competing political authorities, then, generate new opportunity structures in a world of globalization.

This transformation of authority is revealed in how nation-states-generally thought of as sharing coherent and unified interests and national identities-are seeing contestation and a fraying of social solidarity under the stress of the pandemic. In the US, state-level actors such as state governors have clashed with the Trump administration during the pandemic, whether about shelter-in-place orders, PPE sourcing, or face mask requirements, and have reached out globally to seek assistance on their own from other countries and firms. ${ }^{32}$ Notably, these cleavages do not simply map onto partisanship. In Italy, stark differences in the severity of the coronavirus

27. The arguments in this section draw from Farrell and Newman's New Interdependence Approach. For greater elaboration see Farrell and Newman 2014; 2016; 2019a.

28. See Mattern and Zarakol 2016; Mcconaughey, Musgrave, and Nexon 2018; Musgrave and Nexon 2018;

29. Mattern and Zarakol 2016, 624.

30. See Farrell and Newman 2014; Farrell and Newman 2016.

31. Farrell and Newman 2017.

32. Galston 2020. 
in Lombardy and the Veneto meant travel restrictions were imposed between these regions of Northern Italy — even a shared ruling party (the Lega) was not enough to keep their leaders from political strife. ${ }^{33}$ Political authority is also being generated in ways that supersede nation-states themselves, for example in the European Union (EU), as well as through transnational linkages joining political actors and movements globally. ${ }^{34}$ While initially the EU seemed ill-equipped to respond to the pandemic, it has recently moved in surprising ways towards new powers, such as in the fiscal realm, to address European citizens' needs. ${ }^{35}$

In sum, today's globalization is shaped by political authority that neither fits the traditional models of state control nor constitutes a free-for-all of markets over politics. Instead, economic integration is creating new forms of political authority and creating links between other entities that exist outside of the state. As these sites of contention shift, so too do global politics.

\section{Opening the Aperture on a Post-Pandemic Globalization Agenda}

Globalization has not only transformed how we should study global politics theoretically but also has critical implications for the issues we study-starkly revealed in the ways the pandemic has unfolded. Since the initial cases of COVID-19 began multiplying, states have turned supply chains into choke points, certain workers have been redefined as essential, and as governments race to implement contact tracing technologies they find themselves beholden to the technology of transnational firms. ${ }^{36}$ While stories of PPE shipments being rerouted or states fighting over future vaccines seem pulled straight out of a Dan Brown novel, the COVID crisis illuminates longer-term trends. ${ }^{37} \mathrm{We}$ argue that globalization has left the confines of container ships and trade deals and now implicates transformational dynamics in at least four areas: inequality within and across societies, new forms of economic statecraft, existential ecological threats, and the trajectory of the digital revolution. In the following section, we use the COVID crisis to highlight the importance of these issues, and apply our theoretical insights about identity and authority to chart a research agenda for understanding the post-pandemic world.

\section{Inequality in a Globalized World}

As the virus spread from China to the world, its path and initial responses to it revealed much about globalization's linkages. European corporate executives at

34. See Hill, Smith, and Vanhoonacker 2017; McNamara 2015; McNamara 2018; Mérand 2008.

35. See McNamara and Matthijs 2020; Ward 2020.

36. See Farrell and Newman 2020a; Farrell and Newman 2020 b.

37. Farrell and Newman 2020a. 
Asian corporate retreats quickly hopscotched the disease through Swiss mountain towns and Italian villages, while grocery store workers fell ill after the disease was brought home. ${ }^{38}$ Russian oligarchs purchased personal ventilators and New York City elites fled to their second home retreats, even as elderly in Italy and the New York City borough of Queens faced healthcare rationing. While the US, Germany, and China fight over future rights to a potential vaccine, countries like Brazil and South Africa struggle to maintain basic supplies of PPEs. The virus thus puts into stark relief the structural inequality that has resulted from globalization-the radically and racially different lived experiences within states and across them. In contrast to distributional approaches, which stress the relative winners and losers of trade openness or efforts to mitigate these differences, ${ }^{39}$ our transformative approach shifts attention to the ways high levels of stratification of information, money, and goods and services in global economic networks may fundamentally disrupt political contestation, enable the rise of a consequential global plutocracy, and deepen global cleavages among states.

First, inequality alters the nature of political contention within societies, not only because of its material impacts, but because of the way it reshapes people's sense of their political identities and thus their perceived interests. In countries like the US and the UK, where inequality has risen dramatically over the past few decades, the substance of political debates has been transformed from standard left-right redistributive questions to include debates over sovereignty, identity, and immigration. ${ }^{40}$ The rise of global populist politics has many roots, but it is certain that dramatic rises in economic inequality interacting with issues of culture and identity have brought about the electoral success of US president Donald Trump and the UK's vote to leave the European Union. ${ }^{41}$ Inequality in life opportunities and lived experience, as Kathleen McNamara has argued, is important because it generates very different social realities and thus everyday practices for its citizens, something only heightened with the geographic differences in the fallout from COVID-19.42 Robert Reich, former US Secretary of Labor, has suggested that new classes of people have emerged during the pandemic, and that each are experiencing the crisis' impact in dramatically different ways; this felt difference will surely impact politics for years to come. ${ }^{43}$ Experiences with inequality and decline within countries, varying

38. Ian Goldin, "Coronavirus shows how globalization spreads contagion of all kinds," Financial Times, 3 March 2020.

39. There are large and important literatures in IPE that examine how groups are economically affected by trade (e.g. Baccini and Pinto 2017), as well as how states attempt to mitigate or fail to mitigate the political repercussions of these distributional consequences (for example, Rudra 2008).

40. Hooghe and Marks 2018.

41. See Grzymala-Busse 2019; Hopkin 2020.

42. See McNamara 2017; Muro, Whiton, and Maxim 2020; Paul Constant, "The Coronavirus exposed the pre-existing inequality of the American economy," Business Insider, 14 May 2020.

43. Reich 2020. Reich identifies four key groups, from those who can work remotely with little disruption, to the essential workers employed by on the frontline, the unemployed, and those he calls the "forgotten" in places like prisons, immigration detention facilities, migrant farm worker camps, Native American reservations, homeless shelters, and nursing homes. 
significantly by class, race, immigration status, and geographical location, and further sharpened by the pandemic, all contribute to the politics unleased as globalization deepens. ${ }^{44}$ Integrating such deep-seated societal segmentation may help to unravel a number of specific empirical puzzles, including why voters seem to support protectionist policies even when such policies punish their own economic interests. ${ }^{45}$ Moreover, such an approach could open up a debate on the ways markets create cosmopolitan and parochial identities, which could provide the basis for a political economy of closure.

Second, rising inequality has generated a global class of plutocrats whose political impact transcends borders. During the COVID pandemic, plutocrats have in some cases replaced governments as the primary actors in the response both domestically (for example in many Russian cities) as well as internationally (for example the Gates Foundation and vaccine research). ${ }^{46}$ From Bill Gates to Oleg Deripaska, roughly 2000 billionaires control more wealth than 60 percent of the planet. These plutocrats are not simply rich people; they are transforming politics. The Gates Foundation strives to eliminate disease, while many Russian oligarchs help the Putin government spread disinformation. The Koch brothers and the Mercer family have played a central role in supporting conservative movements and right-wing initiatives across the US and Europe, while George Soros has played a similar role on the left. If IPE were to follow the money, it would quickly realize that a handful of players are having an outsized influence on global affairs. ${ }^{47}$ And these actors are not simply attempting to get a bigger slice of the pie but are changing the nature of the game, rewriting formal rules around campaign finance, media ownership, and government regulation. Recognizing the role of plutocrats in IPE would shift our empirical understanding of capital account liberalization, foreign direct investment, and tax havens from debates about how states engage global markets to how individuals use those markets to alter international politics. ${ }^{48}$ The rise of global plutocratic politics also embodies our contention that new sites of political authority and new types of global contestation should be studied and understood to be part of the stratified nature of twenty-first century globalization.

Third, the pandemic has underscored the economic inequality between states in the international system and reignited new global cleavages. ${ }^{49}$ Highlighting the interaction between inequality and identity, UN Secretary-General Antonio Guterres warned in a 2020 address honoring Nelson Mandela that "[COVID-19] is exposing fallacies and

44. Richard Oppel, Robert Gebeloff, K.K. Rebecca Lai, Will Wright and Mitch Smith, "The Fullest Look Yet at the Racial Inequality of Coronavirus," New York Times, 5 July 2020.

45. Rho and Tomz 2017.

46. Anton Troianovski, "As Local Health Systems Buckle, Russia's Oligarchs Take Charge," 7 May 2020; Carl O’Donnel and Mana Mishra, “J\&J in Talks with Japan, Gates Foundation to lock in Deals on COVID-19 Vaccine," Reuters, 16 July 2020.

47. Cooley and Sharman 2017.

48. Kalyanpur 2020.

49. See Barnett's contribution to this issue for a fuller exploration of inequality across states and the Global South in the coronavirus pandemic. 
falsehoods everywhere ... the delusion that we live in a post-racist world, the myth that we are all in the same boat," adding that these global inequalities are pushing the world to a "breaking point." ${ }^{50}$ Erin Lockwood has noted that these divisions have gotten little attention in the study of IPE, despite the field's emphasis on the material impacts of openness and the structure of the global economy. ${ }^{51}$ Lockwood's intervention also cautions us against overly optimistic readings of liberalization that focus on successes of countries like China but less on more peripheral states. Such inequality is not simply a character of the units, which might be underdeveloped, but a structural condition of globalization, in which some states are shunted into a permanent underclass. The variation in the severity of the pandemic across states demands investigation, particularly in terms of the advanced economies versus the global south and the early intriguing data suggesting that some low-income countries, such as Viet Nam, have done much better than others such as Brazil or India.

Globalization generates winners and losers. But it also has the potential to create extreme levels of material, political, and social stratification. To understand the consequences of this concentration of power over and access to global markets, scholars should investigate how inequality is transforming identities, political authority, and opportunity structures across, between, and within states. The global economy is altering the lived experience of people who are being further pushed by the pandemic into unequal groups that are not only divided by money but by matters of life and death.

\section{New Economic Statecraft}

Since the end of the Cold War, a wide consensus emerged among policy-makers and scholars that economic networks for money, information, and production went hand in hand with greater political liberalization and in turn, with global peace..$^{52} \mathrm{~A}$ host of current events, however, make this frame more and more difficult to sustain. From secondary sanctions to technological competition, great powers like the US and China increasingly weaponize economic networks for their strategic gain. Since the outbreak of the COVID crisis, these issues have only become more salient as powerful states manipulate medical supply chains for their own self-interest, use cyberattacks to obtain sensitive vaccine research, and engage in pandemic disinformation campaigns..$^{53}$ Understanding the security dynamics of globalization, then, will be an urgent priority for the field. Using the frame of shifting political authority in a hierarchical world order allows us to see these dynamics at work much more clearly.

50. Antonio Guterres, "Tackling the Inequality Pandemic: A new social contract for a new era," The Nelson Mandela Lecture, 18 July 2020, retrieved from <https://www.un.org/sg/en/content/sg/statement/ 2020-07-18/secretary-generals-nelson-mandela-lecture-\%E2\%80\%9Ctackling-the-inequality-pandemicnew-social-contract-for-new-era\%E2\%80\%9D-delivered>.

51. Lockwood 2020; see also, Kalyanpur 2018.

52. See Brooks 2011; Friedman 2005.

53. See Barnes 2020; Farrell and Newman 2020a; Rankin 2020; Willsher, Borger, and Holmes 2020. 
As Henry Farrell and Abraham Newman argue, the security/economy nexus is not simply about asymmetric interdependence, whereby states manipulate bilateral relations to put pressure on one another. ${ }^{54}$ Instead, global economic networks themselves have become a channel of coercion as states engage in weaponized interdependence. ${ }^{55}$ In many cases, the networks themselves are asymmetric, with some firms more connected to the network than others. This generates new inequalities and power dynamics not only for firms but for the states that control legal access to them. Organizations such as the SWIFT messaging system or global physical infrastructures such as fiber optic cables become tools of coercion and surveillance. Understanding which networks are likely to be deployed in such a fashion will shed light on a range of critical global challenges, including the future of great power rivalry under conditions of interdependence, as well as the logic of the pandemic response.

More generally, a recognition of this new economic statecraft will push IPE to return to fundamental debates concerning the interaction between global markets and power. For much of its early history, work by IPE scholars including Robert Gilpin and Susan Strange focused on the ways markets create power and tools of dominance. ${ }^{56}$ Over time, however, approaches emphasizing cooperation and functionalism tended to view markets as a coordination mechanism rather than a form of control. While a few research agendas on issues like monetary politics and sanctions continued to address such questions, conventional IPE largely came to accept a view of markets that decoupled them from state power. We now need to revisit fundamental questions like the relationship between multinational corporations and national security, and how global firms serve as an extension of state power while also potentially undermining it, as with the pharmaceutical companies and potential vaccine supply chains. Moreover, work on foreign direct investment will need to be more closely coupled with security studies as supply chains become a powerful source of potential vulnerability as well as efficiency. As the COVID crisis makes clear, no nation can afford to ignore the new reality without risking the health and safety of its citizenry in a globalized world.

\section{Existential Ecological Threat}

As pandemic lockdowns brought the industrial world to a halt, a profound disruption in energy use, shipping, and aviation ensued. With the flip of a switch, the world got a taste of a not so distant zero-carbon future, in which the demand for carbon bottoms out. ${ }^{57}$ By April 2020, as lockdowns and travel restrictions became more encompass-

54. Farrell and Newman 2019a.

55. See Rudra 2008; Keohane and Nye 1977.

56. See Gilpin 1976; Strange 1990.

57. Christiana Figueres, "COVID-19 has given us the chance to build a low-carbon future," The Guardian, 1 June 2020. 
ing, overall planetary emissions dropped by seventeen percent, and aviation saw a nearly forty percent drop. For the first time in history oil futures swung negative, meaning sellers had to pay buyers to take their oil.

This dramatic disruption foreshadows how the fallout from climate change is not an externality to the market, but instead redefines it. ${ }^{58}$ As Jeff Colgan, Thomas Hale, and Jessica Green have argued, we are entering a world of existential politics whereby firms face not only distributional implications of policy choices, but also the possibility that their very business models may be eradicated by climate change and the future of alternative energy. ${ }^{59}$ As firm identities are transformed along with their carbon future, it is very difficult to find traditional coordination-based solutions such as issue linkage or side payments to model and solve these essential challenges. Moreover, the extent of the challenge motivates actors facing such existential threats to take on radical approaches-including disinformation and institutional decay strategies-which seek to weaken the entire political system in an effort to limit the ability of policy makers to pursue climate mitigation policies.

As the impacts of climate change continue to be manifested in extreme events around us, the international and comparative political economy scholarly community needs to bridge the traditional divide between those who study green politics domestically and those who study global markets. EU policymakers, for example, are addressing the economic ravages of the pandemic by reassessing their emphasis on a competition policy that prioritizes free markets over national subsidies, and are moving to create a European regime of investment, regulations, and industry collaboration to instead promote green technologies along with global competitiveness. The European Central Bank, long one of the bastions of orthodoxy and conservative monetary policy practices, announced in January 2020 that it was undertaking its first ever comprehensive review of its monetary policy strategy, looking across all its policies and introducing environmental sustainability as a new potential rubric for its policy. ${ }^{60}$ As political authority moves beyond the nation-state, climate response has shifted beyond inter-state deals and national commitments to supranational and transnational arenas.

\section{Digital Revolution}

As societies grapple with the fallout from the pandemic, the pervasive role of digital technology in our lives has become strikingly apparent. From birthday parties to

58. Our survey of IO articles since 2010 shows only 3 (out of 310 ) with environmental issues as a central topic.

59. Colgan, Green, and Hale 2020.

60. Press Release, European Central Bank, "ECB Launches Review of its Monetary Policy Strategy," 23 January 2020, retrieved from <https://www.ecb.europa.eu/press/pr/date/2020/html/ecb.pr200123 3b8d9 fc08d.en.html>. 
company meetings, daily life is dependent on video conferencing platforms like Zoom and Google Hangouts. ${ }^{61}$

The largest companies by stock market valuation are the so-called FAANG ${ }^{62}$, which rely on digital platforms. In many cases, these platforms span jurisdictions, creating truly transnational firms ${ }^{63}$ which often enjoy monopoly or monopsony power. ${ }^{64}$ This extraordinary business success has been achieved in part by using nontraditional business models, which offer services to consumers for "free" in exchange for their data. What has been termed "surveillance capitalism" relies on a few large firms vacuuming up personal information and turning that information into more advanced algorithms and targeted advertising. ${ }^{65}$ This market transformation is not simply an economic affair but is fundamentally altering the nature of markets, actor identities, and the role of national political authorities.

There is a large literature in communication studies which explores how communications technologies shape what and how we interact. The internet, in particular, has altered media engagement and opened up new channels of expression such as social media. While the exact impact on political views is still debated, the companies involved are themselves growing increasingly concerned about effects on political identity. ${ }^{66}$ An exposé in the Wall Street Journal released internal Facebook reports highlighting how "[Facebook's] algorithms exploit the human brain's attraction to divisiveness," promoting "more and more divisive content in an effort to gain user attention \& increase time on the platform." 67 An important research question then examines variation and effectiveness in how political identities may be shaped cross-nationally through these platforms.

At the same time, these technology companies are coming to play an important role in mediating global politics. For example, Twitter and Facebook are facing mounting criticism to more actively tackle disinformation campaigns even as the president of the United States has often amplified these very campaigns, and Zoom recently disconnected a Chinese civil liberties advocate from a global call, bowing to pressure from the Chinese government. ${ }^{68}$ And privacy advocates worry that the pandemic means global contact tracing apps will be used by governments and firms to increase surveillance and control over their societies. ${ }^{69}$ Equally important, governments find themselves constrained by the technical options made available by transnational

61. Andrew Burt, “Three Questions on COVID-19 and Digital Technology," Lawfare, 11 May 2020.

62. FAANG stands for the technology giants Facebook, Amazon, Apple, Netflix, and Google.

63. Kalyanpur and Newman 2019.

64. Culpepper and Thelen 2020.

65. Zuboff 2019.

66. Barberá et al 2019.

67. Jeff Horwitz and Deepa Seetharaman, 2020. Facebook executives shut down efforts to make the site less divisive. The Wall Street Journal. May 26.

68. Gerry Shih, "Zoom censors video talks on Hong Kong and Tiananmen, drawing criticism," Washington Post, 11 June 2020.

69. See Natasha Singer, "Google Promises Privacy with Virus Application but can still Collect Location Data," 20 July 2020; Umberto Bacchi, "Coronavirus surveillance poses long-term privacy threat, UN expert warns," Reuters, 31 March 2020. 
firms. Research on private actor governance, which has long emphasized its coordinating function, will need to spend more time looking at issues of power in markets and its normative consequences.

Finally, states are now using the open information networks of globalization to wage political warfare. The Mueller report made clear how the Russian government views such networks. The Chinese government has increasingly turned to similar disinformation campaigns in the context of the pandemic. ${ }^{70}$ Hackers backed by the Chinese government have recently been charged with attempting to hack into US and UK vaccine research. While the internet was long viewed primarily as a technology that championed liberal goals of free speech and open markets, states have turned it into a vector of attack. ${ }^{71}$ Research on internet governance, then, will need to expand its focus beyond issues of interconnection and standard setting to consider how openness impacts domestic regime stability in democracies. ${ }^{72}$

All that being said, standard IPE has devoted relatively little attention to these issues and how they are transforming global politics. ${ }^{73}$ In our review of articles appearing in International Organization over the last decade, only three focused on digital technology. It is thus critical for IPE scholars to pay more attention to how information flows are altering political identities, opportunity structures, and sites of authority. This will become even more pressing as authoritarian governments and firms from those states-most importantly China-play a greater role in the provision of key information technologies.

\section{Conclusion}

Over the last several decades, globalization has transformed the nature of world politics. Substantively, the issue space has shifted from questions about distribution to questions about profound structural changes related to inequality, security, the environment, and new technology. At the same time, globalization is altering the institutions and opportunity structures available to actors hoping to contest and reset political debates, even as it interacts with the social identities and cultures of those actors. A major implication, then, of our intervention is to focus on the incremental and long-term changes that have been driven by globalization and that are now reinforced by the pandemic. ${ }^{74}$ Rather than an exogenous shock or a return to the mean, the pandemic uncovers blind spots in our existing theoretical toolkit and calls for a reexamination of how IPE engages with globalization. We propose a theoretical

70. Molter, Vanessa and Graham Webster, "Virality Project (China): Coronavirus Conspiracy Claims,"

31 March 2020, retrieved from <https://cyber.fsi.stanford.edu/news/china-covid19-origin-narrative>.

71. Farrell and Newman forthcoming.

72. Farrell and Schneier 2019.

73. Simmons 2011.

74. See Farrell and Newman 2010; 2019; Fioretos 2011; Thelen 2003. 
refocus on the role of identity and shifting political authority in these transformations, so as to better capture the nature of the world around us.

As states restrict exports of key medical goods and governments call for the reshoring of global pharmaceutical supply chains, it may seem seductive to simply put up walls and tear down globalization. Unfortunately, the nationalist path ignores the ways political and economic systems have been deeply intertwined by global economic networks. Ironically, the post-Brexit slogan is "Global Britain," as leaders face the reality that the UK cannot simply withdraw from the world. The best hope for a critically needed vaccine for Americans may come from foreign investment in a German or French company.

Reconstructing global markets in a post-pandemic world cannot rely on old formulas, but instead will demand a reimagining of markets themselves. What constitutes a sustainable and durable set of global market practices that will be durable for the long run? What institutions may be needed to guarantee such behavior? Now is the time for scholars and students of international political economy to address these pivotal questions.

\section{References}

Abdelal, Rawi, Mark Blyth, and Craig Parsons. 2011. Constructing the International Economy. Cornell University Press.

Allee, Todd L., and Jamie E. Scalera. 2012. The Divergent Effects of Joining International Organizations: Trade Gains and the Rigors of WTO Accession. International Organization 66 (2):243-76.

Allee, Todd, and Clint Peinhardt. 2011. Contingent Credibility: The Impact of Investment Treaty Violations on Foreign Direct Investment. International Organization 65 (3):401-32.

Barberá, Pablo, Andreu Casas, Jonathan Nagler, Patrick J. Egan, Richard Bonneau, John T. Jost, and Joshua A. Tucker. 2019. Who leads? Who follows? Measuring Issue Attention and Agenda Setting by Legislators and the Mass Public Using Social Media Data. American Political Science Review 113 (4):883-901.

Barnes, Julian E. 2020. US Accuses Hackers of Trying to Steal Coronavirus Vaccine Data for China. The New York Times. Available at <https://www.nytimes.com/2020/07/21/us/politics/china-hacking-coronavirus-vaccine.html>. Accessed 30 July 2020.

Barnett, Michael, and Raymond Duvall. 2005. Power in International Politics. International Organization 59 (1):39-75.

Barnett, Michael. 2020. Humanitarian Governance, Global Triage, and the International Liberal Sacrificial Order. International Organization 74 (S1). <https://doi.org/10.1017/S002081832000034X>.

Best, Jacqueline, and Matthew Paterson. 2010. Cultural Political Economy. Routledge.

Brooks, Stephen G. 2011. Producing Security: Multinational Corporations, Globalization, and the Changing Calculus of Conflict. Princeton University Press.

Büthe, Tim, and Helen V. Milner. 2008. The Politics of Foreign Direct Investment into Developing Countries: Increasing FDI through International Trade Agreements? American Journal of Political Science 52 (4):741-62.

Buzas, Zoltan. Forthcoming. Racism and Antiracism in the Liberal International Order. International Organization.

Colgan, Jeff, Jessica Green, and Thomas Hale. Forthcoming. Asset Revaluation and the Existential Politics of Climate Change. International Organization. 
Cooley, Alexander, and J.C. Sharman. 2017. Transnational Corruption and the Globalized Individual. Perspectives on Politics 15 (3):732-53.

Culpepper, Pepper D., and Kathleen Thelen. 2020. Are We All Amazon Primed? Consumers and the Politics of Platform Power. Comparative Political Studies 53 (2):288-318.

Drezner, Daniel. 2020. The Song Remains the Same: International Relations After COVID-19. International Organization 74 (S1). <https://doi.org/10.1017/S0020818320000351>.

Farrell, Henry, and Abraham L. Newman. 2010. Making Global Markets: Historical Institutionalism in International Political Economy. Review of International Political Economy 17 (4):609-38.

Farrell, Henry, and Abraham L. Newman. 2014. Domestic Institutions Beyond the Nation-State: Charting the New Interdependence Approach. World Politics 66 (2):331-63.

Farrell, Henry, and Abraham L. Newman. 2016. The New Interdependence Approach: Theoretical Development and Empirical Demonstration. Review of International Political Economy 23 (5):713-36.

Farrell, Henry, and Abraham Newman. 2017. BREXIT, Voice and Loyalty: Rethinking Electoral Politics in an Age of Interdependence. Review of International Political Economy 24 (2): 232-47.

Farrell, Henry, and Abraham L. Newman. 2019a. Of Privacy and Power: The Transatlantic Struggle over Freedom and Security. Princeton University Press.

Farrell, Henry, and Abraham L. Newman. 2019b. Weaponized Interdependence: How Global Economic Networks Shape State Coercion. International Security 44 (1):42-79.

Farrell, Henry, and Abraham L. Newman. 2020a. Will the Coronavirus End Globalization as We Know It? Foreign Affairs. Available at <https://www.foreignaffairs.com/articles/2020-03-16/will-coronavirusend-globalization-we-know-it>. Accessed 19 June 2020.

Farrell, Henry, and Abraham L. Newman. 2020b. Will Governments Restrict Foreign Access to Pandemic Supplies? Harvard Business Review. Available at $<\mathrm{https} / / \mathrm{hbr} .0 \mathrm{rg} / 2020 / 03 /$ will-governments-restrictforeign-access-to-pandemic-supplies>. Accessed 19 June 2020.

Farrell, Henry, and Abraham L. Newman. Forthcoming. The Janus Face of the Liberal International Order: When Global Institutions are Self-Undermining. International Organization.

Farrell, Henry, and Bruce Schneier. 2019. Democracy's Dilemma, Boston Review, May 15.

Fioretos, Orfeo. 2011. Historical Institutionalism in International Relations. International Organization 65 (2):367-99.

Fligstein, Neil. 2002. The Architecture of Markets: An Economic Sociology of Twenty-first-century Capitalist Societies. Princeton University Press.

Friedman, Thomas L. 2005. The World Is Flat: A Brief History of the Twenty-first Century. Macmillan.

Galston, William A. 2020. Trump or Governors: Who's the Boss? Brookings. Available at <https://www. brookings.edu/blog/fixgov/2020/03/25/trump-or-governors-whos-the-boss/>. Accessed 20 June 2020.

Garrett, G. 1998. Global Markets and National Politics. International Organization 52 (4):787-824.

Gilpin, Robert. 1976. The Political Economy of the Multinational Corporation: Three Contrasting Perspectives. American Political Science Review 70 (1):184-91.

Giuffrida, Angela. 2020. Why Was Lombardy Hit Harder Than Italy's Other Regions? The Guardian. Available at <https://www.theguardian.com/world/2020/may/29/why-was-lombardy-hit-harder-covid19-than-italys-other-regions $>$. Accessed 20 June 2020.

Grzymala-Busse, Anna. 2019. Introduction. Polity 51 (4):631-40.

Guisinger, Alexandra. 2017. American Opinion on Trade: Preferences Wthout Politics. Oxford University Press.

Hill, Christopher, Michael Smith, and Sophie Vanhoonacker. 2017. International Relations and the European Union. Third Edition. New European Union Series. Oxford University Press.

Hooghe, Liesbet, and Gary Marks. 2018. Cleavage Theory Meets Europe's Crises: Lipset, Rokkan, and the Transnational Cleavage. Journal of European Public Policy 25 (1):109-35.

Hopkin, Jonathan. 2020. Anti-System Politics: The Crisis of Market Liberalism in Rich Democracies. Oxford University Press.

Kalyanpur, Nikhil. 2018. Hegemony, Inequality, and the Quest for Primacy. Journal of Global Security Studies 3(3): 371-84. 
Kalyanpur, Nikhil. 2020. Liberalism Outsourced: Why Oligarchs and Autocrats Fight in Foreign Courts. Doctoral Dissertation, Washington, DC: Georgetown University.

Kalyanpur, Nikhil, and Abraham L. Newman. 2019. The MNC-Coalition Paradox: Issue Salience, Foreign Firms and the General Data Protection Regulation 57 (3):448-67.

Keohane, Robert O. 2009. The Old IPE and the New. Review of International Political Economy 16 (1):34-46.

Keohane, Robert and Joseph Nye. 1977. Power and Interdependence: World Politics in Transition. Little, Brown.

Lake, David A. 2009. Open Economy Politics: A Critical Review. The Review of International Organizations 4 (3):219-44.

Leong, Nancy. 2013. Racial Capitalism. Harvard Law Review 126 (8):2151-226.

Lockwood, Erin. 2020. The International Political Economy of Global Inequality. Review of International Political Economy. Available at <https://doi.org/10.1080/09692290.2020.1775106>.

Mansfield, Edward D., Helen V. Milner, and Jon C. Pevehouse. 2007. Vetoing Co-operation: The Impact of Veto Players on Preferential Trading Arrangements. British Journal of Political Science 37 (3):403 -32.

Mattern, Janice Bially, and Ayşe Zarakol. 2016. Hierarchies in World Politics. International Organization 70 (3):623-54.

Mcconaughey, Meghan, Paul Musgrave, and Daniel H. Nexon. 2018. Beyond Anarchy: Logics of Political Organization, Hierarchy, and International Structure. International Theory 10 (2):181-218.

McNamara, Kathleen. 2002. Rational Fictions: Central Bank Independence and the Social Logic of Delegation. West European Politics 25 (1):47-76.

McNamara, Kathleen R. 2018. Authority Under Construction: The European Union in Comparative Political Perspective. JCMS: Journal of Common Market Studies 56 (7):1510-25.

McNamara, Kathleen R. 2017. Explaining the New Class Cleavages: Geography, Post-Industrial Transformations and Everyday Culture. SSRN Scholarly Paper. Rochester, NY: Social Science Research Network. Available at <https://papers.ssrn.com/abstract=3059222>. Accessed 30 July 2020.

McNamara, Kathleen R. 2009. Of Intellectual Monocultures and the Study of IPE. Review of International Political Economy 16 (1):72-84.

McNamara, Kathleen R. 1999. The Currency of Ideas: Monetary Politics in the European Union. Cornell Studies in Political Economy. Cornell University Press.

McNamara, Kathleen R. 2015. The Politics of Everyday Europe: Constructing Authority in the European Union. Oxford University Press.

McNamara, Kathleen R., and Matthias Matthijs. 2020. Analysis I Europe's Leaders Meet This Week to Confront the Coronavirus. Washington Post. Available at <https://www.washingtonpost.com/politics/ 2020/04/21/europes-leaders-meet-this-week-confront-coronavirus/>. Accessed 20 June 2020.

Mérand, Frédéric. 2008. European Defence Policy: Beyond the Nation State. Oxford University Press.

Mosley, Layna. 2003. Global Capital and National Governments. Cambridge University Press.

Muro, Mark, Jacob Whiton, and Robert Maxim. 2020. The Places a COVID-19 Recession Will Likely Hit Hardest. Brookings. Available at <https://www.brookings.edu/blog/the-avenue/2020/03/17/the-places-acovid-19-recession-will-likely-hit-hardest/>. Accessed 19 June 2020.

Musgrave, Paul, and Daniel H. Nexon. 2018. Defending Hierarchy from the Moon to the Indian Ocean: Symbolic Capital and Political Dominance in Early Modern China and the Cold War. International Organization 72 (3):591-626.

Owen, Erica, and Noel P. Johnston. 2017. Occupation and the Political Economy of Trade: Job Routineness, Offshorability, and Protectionist Sentiment. International Organization 71 (4):665-99.

Owen, Erica, and Stefanie Walter. 2017. Open Economy Politics and Brexit: Insights, Puzzles, and Ways Forward. Review of International Political Economy 24 (2):179-202.

Persaud, Randolph B., and Alina Sajed, eds. 2018. Race, Gender, and Culture in International Relations: Postcolonial Perspectives. Routledge.

Rankin, Jennifer. 2020. EU says China Behind 'Huge Wave' of Covid-19 Disinformation. The Guardian. Available at <https://www.theguardian.com/world/2020/jun/10/eu-says-china-behind-huge-wavecovid-19-disinformation-campaign>. Accessed 30 July 2020. 
Reich, Robert. 2020. Covid-19 Pandemic Shines a Light on a New Kind of Class Divide and its Inequalities. The Guardian. Available at <https://www.theguardian.com/commentisfree/2020/apr/25/ covid-19-pandemic-shines-a-light-on-a-new-kind-of-class-divide-and-its-inequalities $>$. Accessed 15 June 2020.

Rho, Sungmin, and Michael Tomz. 2017. Why don't trade preferences reflect economic self-interest?. International Organization 71(S1): S85-S108.

Rudra, Nita. 2008. Globalization and the Race to the Bottom in Developing Countries. Cambridge University Press.

Simmons, Beth A. 2011. International Studies in the Global Information Age. International Studies Quarterly 55 (3):589-99.

Smelser, Neil J., and Richard Swedberg, eds. 2005. The Handbook of Economic Sociology: Second Edition. Princeton University Press.

Strange, Susan. 1990. Finance, Information and Power. Review of International Studies 16 (3):259-74.

Thelen, K. 2003. How Institutions Evolve: Insights from Comparative Historical Analysis. In Comparative Historical Analysis in the Social Sciences, 208-40. Cambridge University Press.

Tilley, Lisa, and Robbie Shilliam. 2018. Raced Markets: An Introduction. New Political Economy 23 (5): 534-43.

Ward, Alex. 2020. What Alexander Hamilton has to do With the EU's \$850 Billion Coronavirus Stimulus Plan. Vox. Available at <https://www.vox.com/2020/7/21/21332541/coronavirus-eu-stimulus-merkelbillion-hamilton>. Accessed 25 July 2020.

Willsher, Kim, Julian Borger, and Oliver Holmes. 2020. US Accused of 'Modern Piracy' after Diversion of Masks Meant for Europe. The Guardian. Available at <https://www.theguardian.com/world/2020/apr/ 03/mask-wars-coronavirus-outbidding-demand>. Accessed 30 July 2020.

Zuboff, Shoshana. 2019. The Age of Surveillance Capitalism: The Fight for a Human Future at the New Frontier of Power. PublicAffairs.

\section{Authors}

Kathleen R. McNamara is Professor of Government \& Foreign Service at Georgetown University. She can be reached at krm32@georgetown.edu.

Abraham L. Newman is Professor of Government at the Edmund A. Walsh School of Foreign Service and Director of the Mortara Center for International Studies at Georgetown University. He can be reached at aln24@georgetown.edu.

\section{Acknowledgments}

We thank the participants in the IO-Perry World House workshop as well as the editors at International Organization. We also thank Nikhil Kalyanpur for important feedback and Shea Minter for excellent research assistance. This article is part of a larger initiative, the Global Political Economy Project, which is funded by the Open Society Foundation's Economic Justice Program.

\section{Key words}

globalization; International Political Economy; political authority; identity; digital technology; climate change; economic statecraft; inequality; COVID-19; pandemic 